Jan Warren A. Holgado, MD

Joseph E. Cachuela, MD

Department of Otorhinolaryngology Philippine General Hospital

University of the Philippines Manila
Correspondence: Dr. Jan Warren A. Holgado Department of Otorhinolaryngology Ward 10, Philippine General Hospital Taft Ave., Ermita, Manila 1000 Philippines

Phone number: (632) 5268450

E-mail add: wackywarren2009@yahoo.com

Reprints will not be available from the author.

The authors declared that this represents original material that is not being considered for publication or has not been published or accepted for publication elsewhere, in full or in part, in print or electronic media; that the manuscript has been read and approved by all the authors, that the requirements for authorship have been met by each author, and that each author believes that the manuscript represents honest work.

Disclosures: The authors signed disclosures that there are no financial or other (including personal) relationships, intellectual passion, political or religious beliefs, and institutional affiliations that might lead to a conflict of interest.

\section{Basosquamous Carcinoma of the Neck}

Basosquamous carcinoma, a variant of basal cell carcinoma, is rather rare with an incidence of only $1-2 \%$ of cases. ${ }^{1,2}$ It has a predilection for the head and neck region (95.6\%) with primary sites including the nasal, auricular and periocular area with the neck involved in only $1.1 \%$. ${ }^{1}$ Unlike typical basal cell carcinoma, basosquamous carcinoma behaves more aggressively with a higher tendency for metastasis and recurrence. Its rarity translates to a lack of management guidelines. Because of its pattern of growth and relative aggressiveness, treatment plans must be well laid; recurrence resulting from poor planning may lead to a worse outcome and poorer prognosis.

\section{CASE REPORT}

A 76-year-old male from Western Samar presented with a three-year history of a small raised hyperpigmented pruritic lesion in the left lateral neck that gradually enlarged into a non-healing ulcer that bled occasionally. Incisional biopsy at a provincial hospital revealed findings consistent with squamous cell carcinoma. The patient was advised surgery but opted to consult at our institution.

On examination, a $6 \times 4 \mathrm{~cm}$ erythematous, non-tender ulcer with raised advancing edges and areas of bleeding was evident on level III-IV region of the neck on the left overlying the area of the sternocleidomastoid muscle (Figures $1 \mathrm{~A}, B$ ). Moreover, a $1 \times 1 \mathrm{~cm}$ firm, non-tender, slightly movable level $\mathrm{V}$ lymph node on the left was noted. The rest of the head and neck examination was non-contributory. A repeat incisional biopsy of the mass revealed basosquamous carcinoma. However, no biopsy of the lymph node was performed.

\section{DICUSSION}

Basosquamous carcinoma has been defined by many authors in various ways and these definitions have changed over the years as advancements in pathology paved the way for better histopathologic studies. When newly documented, basosquamous carcinoma was believed to be a transition between basal cell carcinoma and squamous cell carcinoma. It was later considered as a variant of basal cell carcinoma with features of both basal cell and squamous cell carcinomas. Contributions from immunohistochemical studies have recently suggested a continuum of basal cell carcinoma and squamous cell carcinoma, whereby basal cell carcinoma undergoes squamous differentiation leading to the development of basosquamous carcinoma. ${ }^{1,3,4}$ This differentiation appears to alter not only the histologic appearance but also the normal biologic behavior of the tumor. Hence basosquamous carcinoma tends to be more aggressive with higher rates of metastasis and recurrence compared to other variants of basal cell carcinoma (Table 1).

There are no specific morphological and clinical features to distinguish basosquamous carcinoma from other basal cell carcinoma types and from squamous cell carcinoma, hence, the diagnosis is made only after biopsy. Basosquamous carcinoma histologically shows areas with features of basal cell carcinoma (nests of typical basaloid cells that are larger, paler and rounder 
FEATURED GRAND ROUNDS

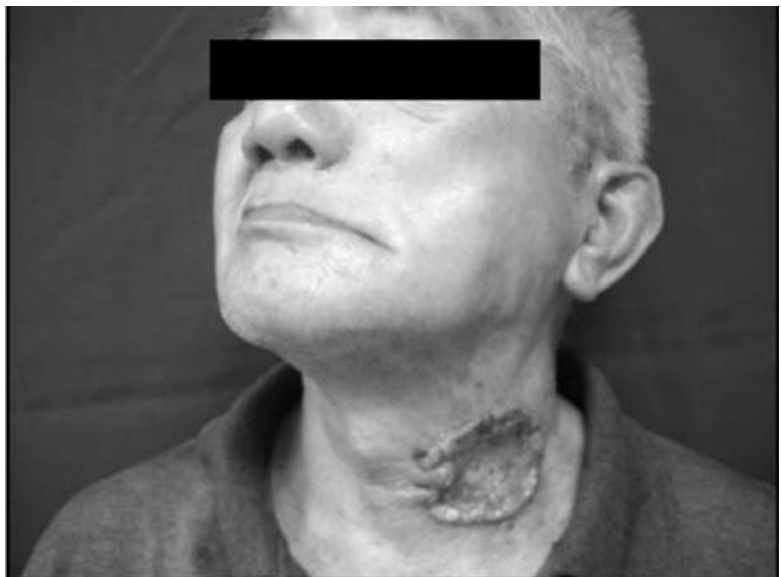

Figure 1 A. A prominent ulcer is noted on level III-IV region of the neck on the left overlying the sternocleidomasoid muscle.

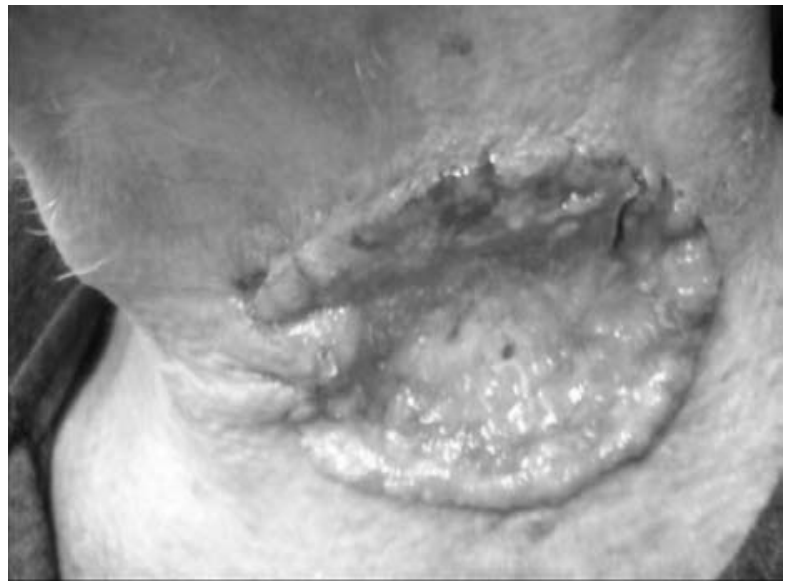

Figure 1 B. Close-up view of the ulcer showing raised advancing edges and areas of bleeding.

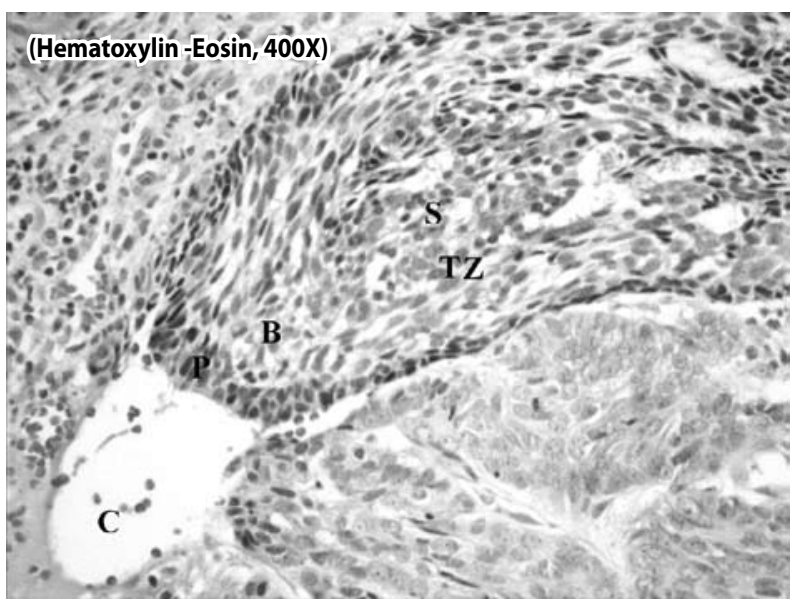

Figure 2. (Light microscopy, Hematoxylin and Eosin stain, high power, 400x): Prominent palisading of basaloid cells are seen with cleft-like retraction spaces between the epithelia nests; towards the center of the nests are cells with more cytoplasm resembling squamous cells. (BC, nest of basaloid cells; $\mathrm{P}$, palisading of peripheral cells; C, clefts; SC, atypical squamous cells; $T Z$, transition zone)
Table 1. Comparison of squamous cell carcinoma, basal cell carcinoma, and basosquamous carcinoma.

\begin{tabular}{|c|c|c|c|}
\hline & $\begin{array}{l}\text { Squamous Cell } \\
\text { Carcinoma }\end{array}$ & $\begin{array}{l}\text { Basal Cell } \\
\text { Carcinoma }\end{array}$ & $\begin{array}{l}\text { Basosquamous } \\
\text { Carcinoma }\end{array}$ \\
\hline Incidence rate & $\begin{array}{l}20 \% \text { of skin } \\
\text { malignancies }^{10}\end{array}$ & $\begin{array}{l}65 \% \text { of skin } \\
\text { malignancies }^{10}\end{array}$ & $\begin{array}{c}1-2 \% \text { of basal cell } \\
\text { carcinomas }^{1,2}\end{array}$ \\
\hline Rate of metastasis & $7.9 \%^{4}$ & $0.09 \%{ }^{4}$ & $4-8.6 \%{ }^{4}$ \\
\hline $\begin{array}{l}\text { Rate of local } \\
\text { recurrence }\end{array}$ & $21.9 \% 4$ & $24.2 \%{ }^{4}$ & $45.7 \%^{4}$ \\
\hline $\begin{array}{l}\text { Predilection for the } \\
\text { head and neck }\end{array}$ & $70 \%{ }^{10}$ & $86 \% \%^{10}$ & $\begin{array}{c}95.6 \%(1.1 \% \text { for } \\
\text { neck only) })^{1}\end{array}$ \\
\hline
\end{tabular}

than solid basal cell carcinoma with peripheral palisading of cells surrounded by retraction clefts), and areas with features of squamous cell carcinoma (squamoid cells that have abundant eosinophilic cytoplasm). ${ }^{5}$ A transition zone with intermediate cells is evident between the area of basal cell carcinoma and squamous cell carcinoma tumor cells. ${ }^{1}$ Figure 2 shows the histologic appearance of the patient's lesion consistent with the aforementioned findings.

The apparent discrepancy between the initial incision biopsy interpretation of squamous cell carcinoma and repeat biopsy findings of basosquamous carcinoma may be attributed to several factors. An inherent characteristic of basosquamous carcinoma that may have played a role in this discrepancy is tumor heterogeneity. ${ }^{6}$ Another important factor would be the adequacy of sampling in terms of technique, location, depth and amount of tissue. Inadequate tissue biopsy coupled with the characteristic tumor heterogeneity can lead to misdiagnosis if only a portion of the lesion showing features of either basal cell carcinoma or squamous cell carcinoma is sampled.

Ideally, imaging of the neck, particularly a CT scan, should have been performed in this case to further evaluate for the extent and depth of involvement of the mass as well as to assess for involvement of other cervical lymph nodes. This is particularly important to allow for pre-operative planning of the surgery since the neck involves other vital structures that may need to be preserved or may have to be sacrificed altogether.

The discrepancy in histopathologic diagnosis has important implications for management. For both squamous cell carcinoma and basosquamous carcinoma, treatment options would either be wide surgical excision or Moh's micrographic surgery. However, since the patient presents with a relatively large lesion located at an unusual location, the choice between wide excision and Moh's surgery differs with the histopathologic diagnosis.

For squamous cell carcinoma, wide surgical excision already offers high cure rates of $\geq 95 \%$ comparable to Moh's surgery. Where the latter surgery would be time-consuming especially for relatively large tumors, 


\section{FEATURED GRAND ROUNDS}

wide excision is preferred. In contrast, basosquamous carcinoma having a higher recurrence rate after wide surgical excision (12-51\%) compared to Moh's surgery (4\%), the preferred mode of treatment is Moh's surgery. ${ }^{2}$

Identified significant factors for recurrence in general include male sex, positive surgical margins, lymphatic invasion, perineural invasion and tumor size. ${ }^{2}$ The patient being a male, with possible lymphatic spread, and having a relatively large tumor put him at increased risk for recurrence should surgery be inadequate. Cases of recurrence have been noted to be more aggressive than the original tumor. ${ }^{2}$

Moh's micrographic surgery is the more appropriate mode of treatment for basosquamous carcinoma. The unusual neck location where other vital structures are present, poses the challenge to preserve as many structures free-of-tumor as possible which can be achieved by Moh's surgery. However, since Moh's surgery is not readily available at our institution and due to the relatively large size of the mass, a more plausible technique is excision with $1.5-\mathrm{cm}$ margin of normal tissue with frozen section. Recurrence rates following cross-sectional frozen section are comparable to those of Moh's surgery at least for basal cell carcinomas. ${ }^{8}$ The procedure would however still leave a huge defect in the neck necessitating reconstruction, in our case with a Trapezius flap. The presence of possible lymph node metastasis warrants a modified radical neck dissection on the left. ${ }^{2}$ The patient should then receive a course of adjuvant radiotherapy. ${ }^{2,9}$

One vital detail illustrated in this case is the importance of biopsy in suspected skin malignancies. The critical role of an adequate biopsy sample and accurate histopathologic diagnosis cannot be understated as they have direct bearing on management and prognosis of skin malignancies. For a rare and aggressive condition as basosquamous carcinoma, knowledge of its natural history and proper management is essential.

\section{REFERENCES}

1. Leibovitch I, Huilgol SC, Selva D, Richards S, Paver R. Basosquamous carcinoma: Treatment with Mohs micrographic surgery. Cancer. 2005 Jul 1;104(1):170-5.

2. Martin II RCG, Edwards MJ, Cawte TG, Sewell CL, McMasters KM. Basosquamous carcinoma: analysis of prognostic factors influencing recurrence. Cancer. 2000 Mar 15;88(6):1365-9.

3. Beer TW, Shepherd P, Theaker JM. Ber EP4 and epithelial membrane antigen aid distinction of basal cell, squamous cell, and basosquamous carcinomas of the skin. Histopathology. [serial on the Internet] 2000 Sep [cited 2010 Mar 4];37(3):218-23.

4. Mitsuhashi T, Itoh T, Shimizu Y, Ban S, Ogawa F, Hirose T et. al. Squamous cell carcinoma of the skin: dual differentiations to rare basosquamous and spindle cell variants. J Cutan Patho [serial on the Internet] $2006 \mathrm{Mar}$ [cited $2010 \mathrm{Mar} 4$ ];33(3):246-52. Available from: http://www3. interscience.wiley.com/journal/118602589/abstract.

5. Kumar V, Abbas AK, Fausto N. Robbins and Cotran Pathologic Basis of Disease. 7th ed. Philadelphia, Pennsylvania: Elsevier Saunders; 2005.

6. Johnson BF, Moore PJ, Goepel JR, Slater DN. Basosquamous carcinoma, a wolf in sheep's clothing? Report of 3 cases. Postgrad Med J. 1989 October; 65(768):750-751.

7. Gross ND, Monroe M. Skin Cancer: squamous cell carcinoma. (article on the Internet) $2009 \mathrm{Jan}$ 15 [accessed 2010 Mar 4]. Available from: http://emedicine.medscape.com/article/870430.

8. Bentkover SH, Grande DM, Soto H, Kozlicak BA, Gillaume D, Girouard S. Excision of head and neck basal cell carcinoma with a rapid, cross-sectional, frozen section technique. Arch Facia Plast Surg [serial on the Internet] Apr-Jun 2002 [cited 2010 Sept 21]:4(2):114-119. Available from: http://archfaci.ama-assn.org/content/4/2/114.

9. Ranjan N, Singh SK, Arif SH. Basosquamous carcinoma in an Indian patient with oculocutaneous albinism. Indian J Dermatol [serial on the Internet] 2009 [cited 2010 Mar 4]:54:63-5. Available from: http://www.e-ijd.org/text.asp?2009/54/5/63/45460.

10. Cummings CW, Flint PW, Haughey BH, Robbins KT, Tomas JR, Harker LA, et.al. Otolaryngology Head and Neck Surgery. 4th ed. Philadelphia, Pennsylvania: Elsevier Mosby; 2005.

11. Garcia C, Poletti E, Crowson AN. Basosquamous carcinoma. J Am Acad Dermatol. [serial on the Internet] 2009 Jan [cited 2010 Mar 4];60(1):137-43. Available from: http://www.ncbi.nlm.nih. gov/pubmed/19103364. 